\title{
ks. Roman Bartnicki, Kinga Kłósek, Metody interpretacji Nowego Testamentu. Wprowadzenie, Wydawnictwo Petrus, Kraków 2014, 291 s.
}

Wiele „niewtajemniczonych” osób sięgających do Pisma Świętego skarży się, że ma problem ze zrozumieniem tego, co czyta i nierzadko zniechęca się do dalszej lektury ksiąg natchnionych. Inni, bardziej wytrwali, gorliwi i ambitni, podejmują próby dotarcia do sensu i przesłania tekstu biblijnego bądź to poprzez bezpośrednio stawiane pytania księżom, osobom zakonnym, katechetom czy innym ludziom bardziej obeznanym z materią, bądź to poprzez własne pogłębione poszukiwania w literaturze fachowej lub - co dziś chyba o wiele powszechniejsze - na stronach internetowych. Problemy z właściwą interpretacją ksiąg świętych nie są obce również tym, którzy z urzędu powołani i zobowiązani są do głoszenia i aktualizacji słowa Bożego nie tylko na ambonie, ale także na współczesnych areopagach, takich jak: prasa, radio, telewizja, strony internetowe, Facebook, Twitter czy inne portale społecznościowe. Także studiujący Pismo Święte i niejako zawodowo się tym zajmujący mają świadomość trudności związanych z jego lekturą, poprawnym rozumieniem i wyjaśnianiem tekstów biblijnych ze względu na ich starożytność, różne warianty dostępnych tekstów i możliwości przetłumaczenia, niemożność dotarcia do pełnej znajomości realiów i warunków religijnych, kulturowych i społecznych ówczesnych czasów oraz z powodu wielości metod interpretacji teksów natchnionych.

Z pomocą w rozwiązywaniu tych i wielu innych wątpliwości - zwłaszcza studentom biblistyki i piszącym prace dyplomowe z Pisma Świętego 
Sprawozdania i recenzje

- przychodzi prezentowana pozycja ks. prof. Romana Bartnickiego i Kingi Kłósek, która stanowi nie tylko wprowadzenie do metod interpretacji Nowego Testamentu, lecz o wiele bardziej metodologię. Jak przyznaje ks. Bartnicki w Przedmowie (s. 5), za podstawę opracowania służyły mu przede wszystkim znane, klasyczne dzieła jak: Thomasa Södinga, Methodenbuch zum Neuen Testament, Freiburg im Breisgau 1998, Martina Ebnera i Bernharda Heiningera, Exegese des Neuen Testaments. Ein Arbeitsbuch für Lehre und Praxis, Paderborn-München-Wien-Zürich 2005 oraz Wilhelma Eggera i Petera Wicka, Methodenlehre zum Neuen Testament. Biblische Texte selbstständig auslegen, Freiburg im Breisgau 2011. Te i inne, bardzo cenne i ważne dla warsztatu biblisty pozycje dostępne są jednak w języku niemieckim, niestety coraz mniej popularnym i znanym wśród osób młodszych. Tym bardziej z radością i uznaniem przyjąć należy omawiane opracowanie, które w przejrzysty i zrozumiały sposób przedstawia tę nieodzowną dla interpretatorów Biblii problematykę w języku polskim.

Praca ks. Bartnickiego i Kingi Kłósek składa się z dwóch zasadniczych części. Pierwsza z nich (s. 7-200) autorstwa ks. prof. Bartnickiego poświęcona została metodzie historyczno-krytycznej, która - jak zauważa autor w Przedmowie (s. 5) - jest preferowana przez Papieską Komisję Biblijną w wydanym w 1993 roku dokumencie Interpretacja Biblii w Kościele. Druga część (s. 201-243) napisana przez Kingę Kłósek prezentuje metodę analizy narracyjnej. Omówienie metod interpretacji poprzedza Przedmowa ks. Bartnickiego (s. 5) i krótki wykaz ważniejszych skrótów (s. 6), a kończą Podsumowanie (s. 243), Przypisy (s. 245-284) i Spis treści (s. 285-291).

Większą część omawianej pozycji zajmuje dokładna prezentacja metody historyczno-krytycznej, którą autor podzielił na trzynaście rozdziałów, opatrzył krótkim wstępem i dodał trzy aneksy: 1. Historia metody historyczno-krytycznej (s. 187-191), 2. Ważniejsze metodologie (s. 192-193), 3. Podstawowe zasady cytowania (s. 195-200). Omawianie poszczególnych etapów badań metodą historyczno-krytyczną rozpoczyna ks. prof. Bartnicki w rozdziale pierwszym (s. 11-16) od wyboru tematyki czyli opracowania jakiegoś tekstu natchnionego lub poszukiwania znaczenia terminu czy pojęcia występującego w Biblii oraz wyboru metody interpretacji egzegetycznej, wskazując przy tym na nieodzowność metody historyczno-krytycznej. W rozdziale drugim (s. 17-29) zatytułowanym Studium okoliczności powstania konkretnego dzieła (dawniej: krytyka historyczna) autor przedstawia nie tylko historię i zadania tej metody, ale zestawia też najważniejsze polskie i obcojęzyczne leksykony i encyklopedie biblijne oraz introdukcje 
do Nowego Testamentu, co stanowi świetną wskazówkę dla młodych badaczy. Rozdział trzeci (s. 30-39) pt. Tekst Nowego Testamentu i jego tłumaczenia zawiera zestawienie oryginalnych wydań tekstu Nowego Testamentu, jego starożytnych tłumaczeń, tłumaczeń na język polski i listę słowników i gramatyk pomocnych w tłumaczeniach tekstów oryginalnych Biblii.

W rozdziale czwartym Krytyka tekstu (s. 40-56) znajdujemy m.in. listę podręczników krytyki tekstu, zadania i historię tej metody, spis najważniejszych rękopisów greckich: papirusów, majuskułów, minuskułów i lekcjonarzy oraz opis procesu przekazu tekstu Nowego Testamentu. Rozdział piąty Analiza kontekstu (s. 57-61) prezentuje krótki rys historyczny tej metody, jej zadania i sposób postępowania. Rozdział szósty Analiza morfologiczno-syntaktyczna (inaczej: analiza formy lub analiza lingwistyczna) (s. 62-77) obok historii i podstawowych zadań tej metody przedstawia językowo-syntaktyczne cechy tekstów: słownictwo, gramatykę, powiązanie słów i wyrazów oraz style i podział tekstu. Zawiera też przydatne, bardzo konkretne wskazania praktyczne do stosowania tej metody i przykłady polskojęzycznych prac egzegetycznych, w których zastosowana została analiza lingwistyczna i analiza retoryczna. W rozdziale siódmym Analiza narracji (s. 78-89), po krótkim przypomnieniu historii i podstawowych funkcji tej metody, sposób postępowania opisano w formie pytań dotyczących: wydarzeń, bohaterów, okoliczności, narratora i perspektywy narracji, adresatów, narracyjnych wzorów i literackich środków stylistycznych oraz zamieszczono kilka przykładów polskich opracowań napisanych tą metodą, co stanowi świetny materiał poglądowy.

Rozdział ósmy Krytyka literacka (s. 90-104) przybliża model i etapy analizy diachronicznej, zadania tej metody i modele wyjaśniające proces literacki tworzenia tekstów Nowego Testamentu, wylicza synopsy i konkordancje - narzędzia tej metody oraz takie oznaki niejednolitości tekstu, jak: podwojenia i powtórzenia, napięcia i sprzeczności, nierówności stylistyczne, dublety i paralele oraz połączenie gatunków, zawiera też wskazówki praktyczne do pracy tą metodą nad tekstami synoptycznymi i niesynoptycznymi. W rozdziale dziewiątym Studium gatunku literackiego (oraz Sitz im Leben) (s. 105-115) ks. Bartnicki przypomina najpierw gatunki literackie wyróżnione przez twórców metody Formgeschichte: Martina Dibeliusa i Rudolfa Bultmanna, a następnie propozycje takich późniejszych autorów, jak: Heinrich Zimmermann (siódme wydanie przepracowane na nowo przez Klausa Kliescha), Georga Streckera, Klausa Bergera, Davida E. Aune i Detleva Dormeyera, podaje literaturę na temat gatunków literackich i w zwięzły 
sposób opisuje analizę Sitz im Leben gatunku literackiego. W rozdziale dziesiątym Krytyka tradycji (s. 116-125) autor z powodu różnych ujęć zadań tej metody charakteryzuje najpierw zwięźle propozycje takich autorów, jak: Georg Strecker, Udo Schnelle, Wilhelm Egger, Thomas Söding, Martin Ebner i Bernhard Heininger oraz przedstawia poszczególne etapy pracy tą metodą i krytykę tradycji tekstów ewangelicznych i epistolarnych Nowego Testamentu.

Jedenasty, najdłuższy rozdział w tej części opracowania pt. Historia redakcji (s. 126-157) rzuca światło na historię i cel tej metody, model

Sprawozdania i recenzje powstawania tekstu, przejawy pracy redakcyjnej i twórczej ewangelistów. Opisuje również sposób przeprowadzenia analizy krytyczno-redakcyjnej, który zawiera synoptyczne porównanie tekstu, wybór i uporządkowanie materiałów, porównanie struktur i kontekstów, pytanie o priorytety teologiczne ewangelisty i przyporządkowanie autorskie, czasowe, geograficzne i teologiczne oraz - co zasługuje na szczególną pochwałę - konkretne przykłady: rozdzielania tradycji od redakcji i poszukiwania priorytetów teologicznych u Ewangelisty Mateusza, analizy redakcji tekstu Ewangelii Markowej i analizy redakcji tekstu Ewangelii Łukasza. W dwunastym rozdziale zatytułowanym Ipsissima verba et facta Jesu (s. 158-163) autor ukazuje próby dotarcia do autentycznych słów i czynów Pana Jezusa. Wylicza przy tym takie najważniejsze kryteria autentyczności, jak: wielorakie poświadczenia, nieciągłości wobec judaizmu i wczesnego Kościoła, ciągłości ze środowiskiem oraz nauką i działalnością Jezusa, stylu Jezusa oraz podaje przykład ich zastosowania do przedpaschalnej misji uczniów do Izraela. Ostatni prezentujący metodę historyczno-krytyczną, trzynasty rozdział nosi tytuł Interpretowanie tekstów biblijnych (czyli praktyczne wskazania dla sposobu objaśniania tekstu) (s. 164-). Zawiera on spis narzędzi pracy egzegety: komentarzy do poszczególnych ksiąg Nowego Testamentu, słowników teologiczno-biblijnych i biblijnych, literatury rabinicznej, apokryfów Starego i Nowego Testamentu, opublikowanych tekstów z Qumran, Józefa Flawiusza, Filona Aleksandryjskiego, hellenistycznych tekstów paralelnych do tekstów Nowego Testamentu i dotyczących środowiska Nowego Testamentu, encyklopedii starożytności i starożytnej literatury chrześcijańskiej. Ksiądz prof. Bartnicki przedstawia tu również sposób przeprowadzenia egzegezy, która - jak słusznie stwierdza: „powinna być wszechstronna i obejmować cały wachlarz metod egzegetycznych. Powinna uwzględniać filologię, sięgać do wiadomości historycznych, objaśniać pojęcia i poglądy epoki” (s. 181).

Druga część omawianej publikacji (s. 201-243) autorstwa Kingi Kłósek to prezentacja metody analizy narracyjnej, która, posługując się 
sformułowaniem autorki, ,skupia się na tekście biblijnym i sprawdza, w jaki sposób funkcjonuje on jako narracja. Traktuje tekst jako całość. Zarówno jego zawartość merytoryczną, jak i sposób, w jaki został skomponowany czy opowiedziany" (s. 203). W rozdziale pierwszym (s. 205-211) Kinga Kłósek przypomina najpierw model komunikacyjny dla tekstu biblijnego, koncentrując się na zagadnieniach rzeczywistego i domyślnego autora i czytelnika oraz narratora i odbiorcy narracji. Drugi rozdział pt. Treść opowiadania (Story) (s. 212-232) poświęcony został konstytutywnym elementom opowiadania, takim jak: wydarzenia (events) i fabuła (plot), bohaterowie (characters) i okoliczności (settings). Rozdział trzeci Sposób opowiadania (Discourse) (s. 233-242) koncentruje się na punkcie widzenia (point of view) narratora oraz na retoryce i stylu. Autorka omawia następujące „techniki” retoryczne: powtórzenie, pominięcie, ironia, symbolizm, obramowanie narracji, dialogi, figury retoryczne i figury myślowe.

Omawiana pozycja nie stanowi nowego ujęcia problematyki, ale z pewnością jest swoistym kompendium, które jak w pigułce zawiera wszystkie niezbędne informacje dotyczące analizy i interpretacji tekstów nowotestamentalnych, do którego chętnie sięgać będą zarówno studenci teologii i biblistyki, magistranci, licencjusze i doktoranci stawiający pierwsze kroki na ścieżkach egzegetycznych poszukiwań, jak i doświadczeni naukowcy. Praca doświadczonego i znanego polskiego egzegety ks. prof. Romana Bartnickiego i Kingi Kłósek bowiem w syntetyczny, zrozumiały sposób wprowadza w annały pracy nad Biblia. Prowadzi przez wszystkie etapy preferowanej przez Papieską Komisję Biblijną metody historyczno-krytycznej, niejako od przedszkola po ostatnią fazę edukacji.

Niewątpliwą zaletą opracowania jest również to, że oprócz klarownej prezentacji metody historyczno-krytycznej, jak i metody analizy narracyjnej zawiera ono niejako kompendium najważniejszych materiałów źródłowych, klasycznych dzieł i opracowań w postaci wykazów istotnych i wartościowych pozycji - polskich i obcojęzycznych: niemieckich, angielskich, francuskich i włoskich - z zakresów poszczególnych etapów omawianej metody. Na uwagę zasługują też krótkie, choć bardzo cenne i trafne charakterystyki i krytyczne oceny ks. prof. Bartnickiego, dotyczące poszczególnych leksykonów, słowników, introdukcji, serii wydawniczych komentarzy biblijnych etc. Warte odnotowania są również zaproponowane przez autora polskie przekłady niektórych terminów egzegetycznych, które różnie tłumaczyli wcześniejsi autorzy.

Nie można przemilczeć też faktu, że przy prezentacji poszczególnych etapów metody historyczno-krytycznej jasno wyłożona została historia, 
zadania i sposób postępowania tej metody. Lepsze zrozumienie metod i sposobu posługiwania się nimi ułatwiają też często konkretnie postawione czytelnikowi pytania. $\mathrm{Na}$ szczególną uwagę zasługują również konkretne przykłady pracy na tekstem biblijnym, np. sposób przeprowadzenia analizy krytyczno-redakcyjnej. Przy przedstawianiu analizy narracyjnej zmieszczone zostały schematy, które pozwalają lepiej zrozumieć model komunikacyjny.

Pewnym mankamentem opracowania jest to, że przypisy nie znajdują się na tej samej stronie, gdzie jest cytowany materiał, a dopiero pod koniec książki, co utrudnia docieranie do nich. Nie ma to jednak wpływu na wartość merytoryczną opracowania.

Podejmując próbę bardzo krótkiej oceny prezentowanej pozycji ks. Bartnickiego i Kingi Kłósek Metody interpretacji Nowego Testamentu. Wprowadzenie, można stwierdzić, że książka ta powinna znaleźć się w biblioteczce każdego zajmującego się interpretowaniem tekstów biblijnych, zarówno studenta, licencjata, doktoranta, jak i profesora. Z pewnością może pełnić rolę podręcznika, metodologii i swoistej zwartej bibliografii nowotestamentalnej. 